\title{
Production of Paperboard Briquette Using Waste Paper and Sawdust
}

\author{
J.K. Odusote*, a S.A. Onowumab and E.A. Fodeke ${ }^{b}$ \\ $a^{*}$ Department of Materials and Metallurgical Engineering, University of Ilorin, Ilorin, Nigeria. \\ bDepartment of Mechanical Engineering, University of Ilorin, Ilorin, Nigeria.
}

Received 30 December 2014; Accepted 11 November 2015

\begin{abstract}
Nigeria has abundant supplies of biomass resources and agro-forestry residues (waste), including sawdust, whose potentials are yet to be fully utilized for economic advantage. This study was undertaken to investigate the properties of paperboard briquettes produced from a mixture of shredded waste paper (pulp) and sawdust using starch as binder. The paperboard briquettes were produced manually by compressing soaked mixtures of pulp and sawdust in a wooden mould $(28 \mathrm{~cm} \times 28 \mathrm{~cm} \times 1 \mathrm{~cm})$ with a compressive load of $26 \mathrm{~kg}$ in the mixing ratios (by weight) 100:0, 70:30, 50:50, 70:30, and 0:100 of pulp to sawdust, respectively. The compressed mixtures were sun dried for three days to ensure proper drying and free from moisture. Density, compressive and tensile tests were carried out on the test samples. The results showed that mass and density of the paperboard increased with increased amount of the sawdust in the mixture. Test results showed that compressive strength decreases as the sawdust content increases. Sample A, which is $100 \%$ paper, had a compressive strength of 5215 $\mathrm{kPa}$, while Sample E, which is $100 \%$ sawdust, had a compressive strength of $22.02 \mathrm{kPa}$. It was also observed that sample B, which is $70 \%$ pulp and $30 \%$ sawdust, had the highest tensile strength of $0.629 \mathrm{kPa}$. However, the tensile strength reduces as the sawdust ratio in the mixture increases. The tensile strength of sample E (100\% sawdust) could not be determined because the sample failed to bind properly. It was concluded that paperboard briquettes can be produced using paper and sawdust, which are generally considered wastes.
\end{abstract}

Keywords: Pulp, Sawdust, Compressive strength, Tensile strength, Paperboard.

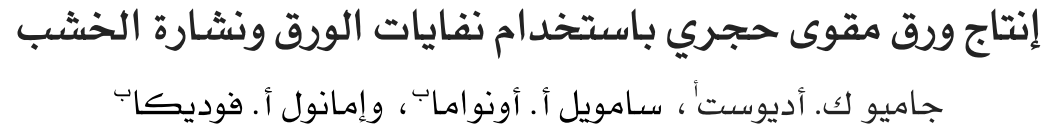

الملخص: نيجيريا لديها امدادات وفيرة من موارد الكتلة الحيوية ومخلفات الحراجة الزراعية (النفايات)، بما بِّذ ذلك نشارة الخشب، لم تستخدم إمكاناتها استخداما كامهلا لفائدة الاقتصاد حتى الآن . وقد أجريت هذه الدراسة من أجل التعرف على خصائص قوالب الورق المقوى الناتجة من خليط ورق النفايات الممزق (اللب) ونشارة الخشب باستخدام النشا كمادة

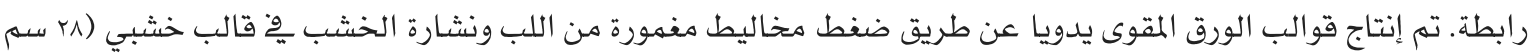

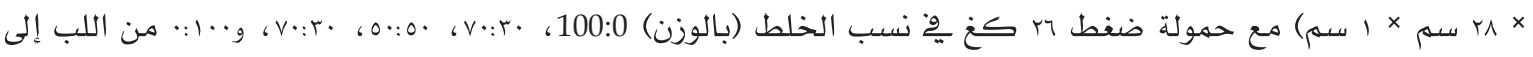
نشارة الخشب، على التوالي. وأظهرت النتائج أن كتلة وكثافة الورق المقوى زادت مع زيادة كمية نشارة الخشب ِو

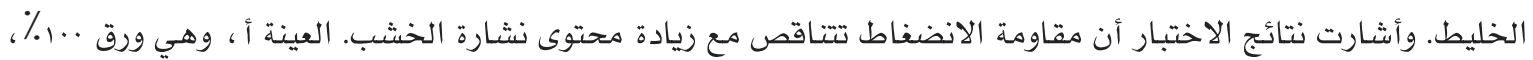
كانت مقاومة الانضغاط لها هابه كيلو باسكال، ـو حين العينة إ، والتي هي ..ر٪ نشارة خشب، كانت مقاومة

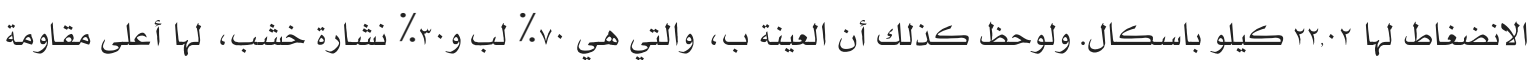
شد وهي 0.629 كيلو باسكال. ومع ذلك، فإن مقاومة الشد تقل مع زيادة نسبة نشارة الخشب يخ الخليط. إن مقاومة الشد عْ عينة إي (...٪ نشارة الخشب) له يتمكن من تعيينها ، وتم استنتاج أن قوالب الورق المقوى يمكن أن يتم إنتاجها باستخدام الورق ونشارة الخشب، والتي هي بالعادة تعتبر من النفايات.

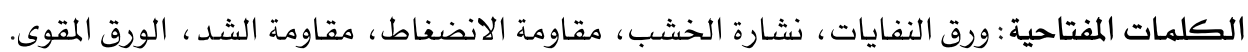

* Corresponding author's e-mail: jaminkolawole@gmail.com 


\section{Introduction}

Paper is a thin material produced by pressing together moist fibres, typically cellulose pulp derived from wood, fibrous materials and nonwood fibrous materials, and drying them into flexible sheets (Cocca et al. 2011). Paper is one of the necessities of civilization and it is almost impossible to imagine the continuance of a world without the printed books and newspapers. Though paper, is most commonly used for writing and printing upon, but also found applications include usage as a packaging material, industrial and construction purposes among others (Brozek and Novakova 2013). These and many more of its uses make it almost impossible to have a halt in its production. In addition, wastes generated through the paper usage are also transformed into other value-added products such as fiber-cement composites (Thaemngoen et al. 2003), granular and sheet activated carbon (Littrell et al. 2000; Uradei et al. 2000; Khezami et al. 2007; Masahiro et al. 2004; Malikov et al. 2007; Yorgun et al. 2009), and activated carbon monoliths (Kercher and Nagle 2003; Nakagawa et al. 2007).

Sawdust or wood dust, which is a by-product of cutting, drilling, sanding, or otherwise pulverizing wood with a saw or other tools, is constantly in production in every workshop where wood work is carried out (Rizki et al. 2010). Wood dust can also be by-product of certain animals, birds and insects which live in wood, such as the woodpecker and carpenter ant (Kuti 2009). Sawdust has quite a number of practical uses, including production of particle board, absorbent materials used in laboratories and poultry farms, fuel sources, among others.

Over the years, several attempts have been made towards reducing, recycling and reusing industrial, commercial, as well as domestic wastes and this has been a subject of research hitherto. The prevalent habit of getting rid of the waste in Nigeria is by burning as depicted in Fig. 1(a \& b), which is hazardous to the environment and human health. Sawdust is indiscriminately disposed into the environment in and around the wood processing industries (Fig. 1), and is often hazardous to health and safety. Sawdust becomes a potential health problem when, for example, the wood particle from processes such as sanding become airborne and inhaled. Sawdust is a known human carcinogen (Aina et al. 2009).
Having seen the rate of production and use of paper and sawdust, it has become imperative to develop ways of processing their waste through recycling, reusing and transforming them into value-added products. Many products have been developed from waste paper and sawdust over the years (Cocca et al. 2013), and these include products like fibre-cement composites, granular and sheet activated carbon, activated carbon monoliths, particle board and paper briquette (Tangsathit and Sanongrai 2012), sawdust briquette (Aina et al. 2009; Emerhi 2011). This project work will be considering the production and analyses of paper boards from waste paper and sawdust with varying composition of paper and sawdust.

This project work will be of great importance because it will serve as a way of conversion of solid wastes to useful product. The present work is significant because it will solve the problems associated with waste paper disposal in academic environment and convert them into other useful products in the same environment. These products will find application as notice board in offices and around the university community. It can also serve as particle board for demarcation of class rooms and laboratories. The waste paper will be mixed with saw dust which is also readily available from local sawmill and furniture workshops. This will help in reducing atmospheric pollution resulting from burning, which is the common way of getting rid of waste paper and sawdust. Another important aspect of this project is that since materials needed are readily available, it will be economical and may serve as a means of livelihood for the unemployed.

\section{Mater ials and Method}

The materials used for the production of the paper board include waste papers (A4), sawdust (mahogany wood) and starch. The waste papers are shredded manually using razor blade and scissors prior to soaking in water as shown in Figs. $2 \mathrm{a}$ and $2 \mathrm{~b}$. The sawdust was also soaked in water to allow for softening before further processing (Fig. 2c). The shredded paper was soaked for 3 hours which is the most appropriate soaking time for paper (Tangsathit and Sanongraj 2012) prior to pounding to obtain fine pulp. The sawdust was also soaked for about 4 hours in a separate container to ensure an eventual proper and uniform mixing with the pulp.

After soaking and pounding, the pulp was collected and drained to remove the water content. The same was also done for the soaked sawdust. 
The drained water can be reclaimed for re-usage or used for other purposes such as block making. This was followed by thorough mixing of the pulp and soaked sawdust, in varying proportion by mass as shown in Table 1 and 2 with $200 \mathrm{~g}$ of starch as the
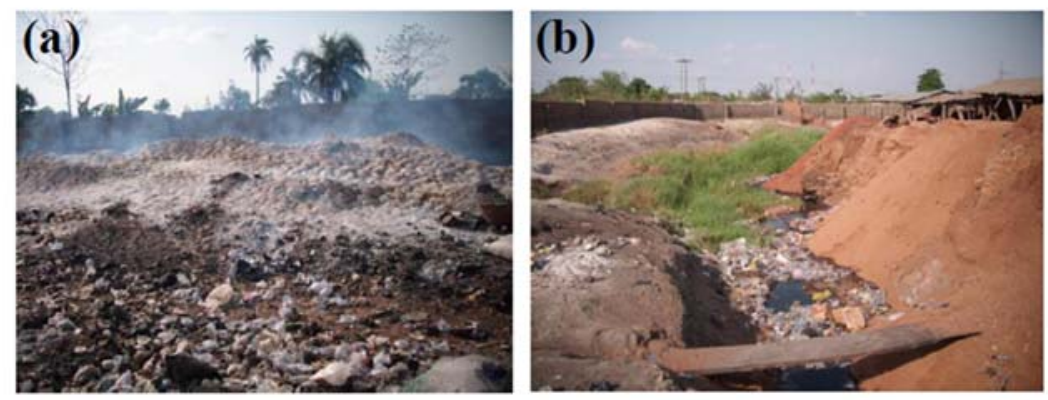

Figure 1. (a) Burning of wood waste, and (b) Disposal of wood waste along drainage.
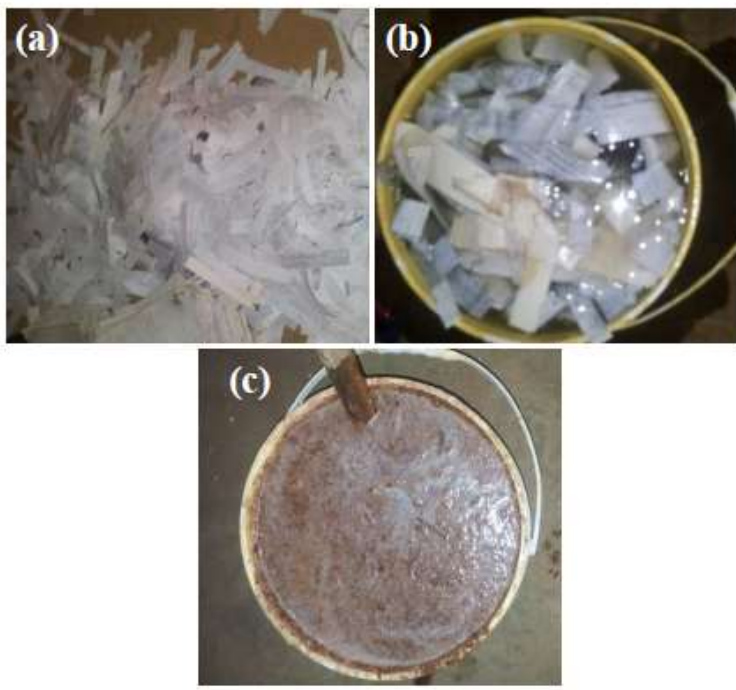

Figure 2. (a) Shredded paper, (b) Soaked shredded paper, and (c) Soaked sawdust.

binder. The briquettes were prepared by pouring the mixture into moulds of equal size $(28 \mathrm{~cm} \times 28$ $\mathrm{cm} \times 1 \mathrm{~cm}$ ), and they were compressed by placing a mass of $26 \mathrm{~kg}$ on each of them. The mass placed on the five samples are left for two days after which the boards with the moulds were sun dried for 3 days for complete drying (Fig. 3).

\section{Sample Testing}

The five briquette samples were tested to determine the following parameters: mass, density, percentage moisture loss, tensile stress and rupture force at point of failure.

\subsection{Mass}

The mass of each of the briquettes before and after sun drying was determined using a weighing balance. Each of the samples was weighed three times for accuracy and the average values were obtained from the readings (Fig. 4).

\subsection{Density}

The volume of the boards is uniform and was calculated to be $756.25 \mathrm{~cm}^{3}$. Hence, the density of each of the briquette was determined as the ratio of mass against volume. 
Table 1. Composition of pulp and sawdust in the paperboard briquette.

\begin{tabular}{ccc}
\hline Sample label & Pulp (wt. \%) & Sawdust (wt. \%) \\
\hline A & 100 & - \\
B & 70 & 30 \\
C & 50 & 50 \\
D & 30 & 70 \\
E & - & 100 \\
\hline
\end{tabular}

Table 2. Mean mass of the wet and dry briquette and the mean moisture loss of different samples after sun drying.

\begin{tabular}{c|c|c|c|c}
\hline \multirow{2}{*}{ Sample label } & \multicolumn{3}{|c|}{ Mean mass of the briquettes $(\mathrm{g})$} & \\
\cline { 2 - 4 } & Wet $\left(\boldsymbol{m}_{\boldsymbol{i}}\right)$ & Dry $\left(\boldsymbol{m}_{\boldsymbol{o}}\right)$ & $\begin{array}{c}\text { Difference }\left(\boldsymbol{m}_{\boldsymbol{i}}\right. \\
\left.-\boldsymbol{m}_{\boldsymbol{o}}\right)\end{array}$ & $\begin{array}{c}\text { Moisture loss } \\
\mathbf{( \% )}\end{array}$ \\
\hline $\begin{array}{c}\text { A (100\% pulp) } \\
\text { B (70\% pulp, 30\% }\end{array}$ & $936.0 \pm 2$ & $180.0 \pm 1$ & $756.0 \pm 1$ & $80.77 \pm 0.07$ \\
$\begin{array}{c}\text { sawdust) } \\
\text { C (50\% pulp, } 50 \%\end{array}$ & $1038.0 \pm 2$ & $274.0 \pm 1$ & $764.0 \pm 1$ & $73.60 \pm 0.05$ \\
$\begin{array}{c}\text { sawdust) } \\
\text { D (30\% pulp, } 70 \%\end{array}$ & $1122.0 \pm 1$ & $275.0 \pm 1$ & $847.0 \pm 0$ & $75.49 \pm 0.07$ \\
$\begin{array}{c}\text { sawdust) } \\
\text { E (100\% sawdust) }\end{array}$ & $1072.0 \pm 2$ & $335.0 \pm 1$ & $737.0 \pm 1$, & $68.75 \pm 0.04$ \\
\hline
\end{tabular}

\subsection{Moisture Loss}

The masses of the briquettes are determined before and after sun drying. Moisture content is calculated using Eqn. 1.

$$
\text { Moisture Loss }=\frac{m_{i}-m_{0}}{m_{i}} \times 100 \%
$$

where $m_{i}$ is the mass of the paperboard briquette before sun drying, and $m_{0}$ is the mass after sun drying.

\subsection{Tensile Strength}

Each briquette samples was cut into 3 sections. The length and width of each section is measured. The maximum tensile load of each sample was determined using the centre loading method according to the British standard, BS 4415-1:1992 (British 1992). The samples were incrementally loaded until failure occurred. When the sample test broke, the maximum load used was recorded.

The tensile stress of each section is calculated according to Eqn. 2 (Tangsathit and Sanongraj

2012). The average values of the tensile stresses of the samples are determined.

Tensile Stress $(\mathrm{Pa})=\frac{P}{b x l}$

\subsection{Compressive Test}

The method used for the present work has been previously reported for testing briquettes made from different non-metallic (Novakova and Brozek 2011) and metallic materials (Plistil et al. 2004). The briquettes were weighed and measured according to the British standard, BS 1SO 12192:2002 (British 2002), before placing each of them between the plates of the universal tensile testing machine and continuously loaded until the briquette ruptures as shown in Fig. 5. The test is completed when the briquette ruptures which is accompanied with the rapid load decrease. The maximum load prior to rupture is noted from the load indicator (Brozek and Novakova 2013).

\section{Results and Discussion}

The photographs of the final dried briquette samples are presented in Figs. 6a to 6e, which revealed the color, shape and size of the finished briquette samples. Sample A contains 100\% pulp, Sample B contains $70 \%$ pulp and $30 \%$ sawdust, while sample $C$ has equal amount of pulp and sawdust. Sample D contains 30\% pulp with $70 \%$ sawdust and Sample E is $100 \%$ sawdust.

\subsection{Mass of the Briquette Samples}

Mass of briquette before sun drying was determined and the values recorded are given in 


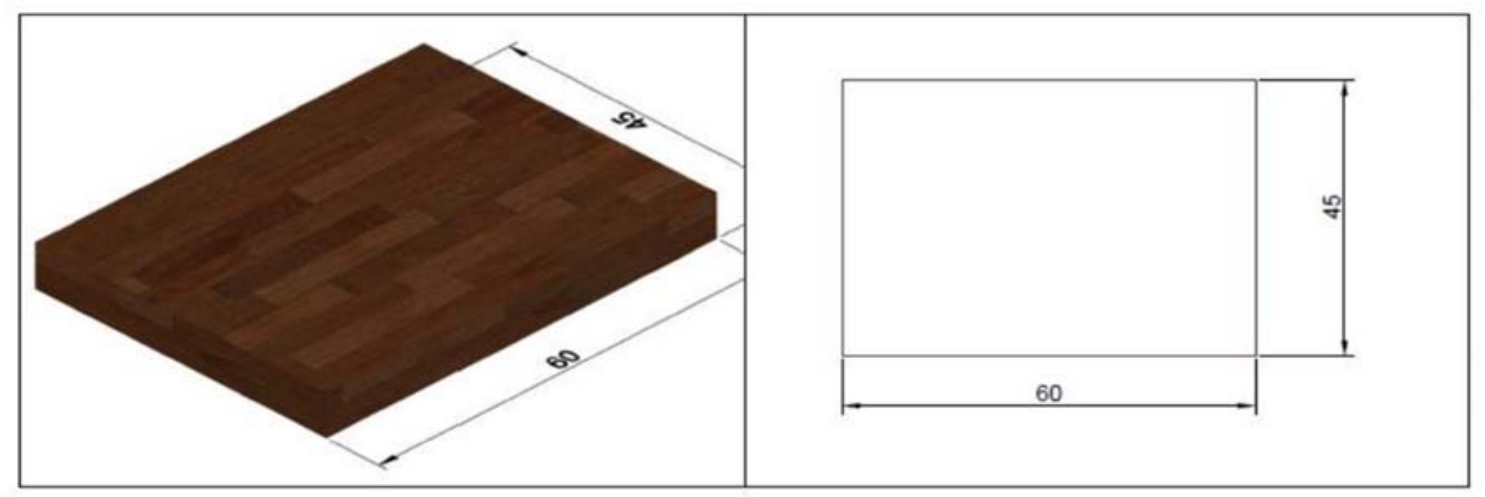

Figure 3. Isometric view of the wooden mold.

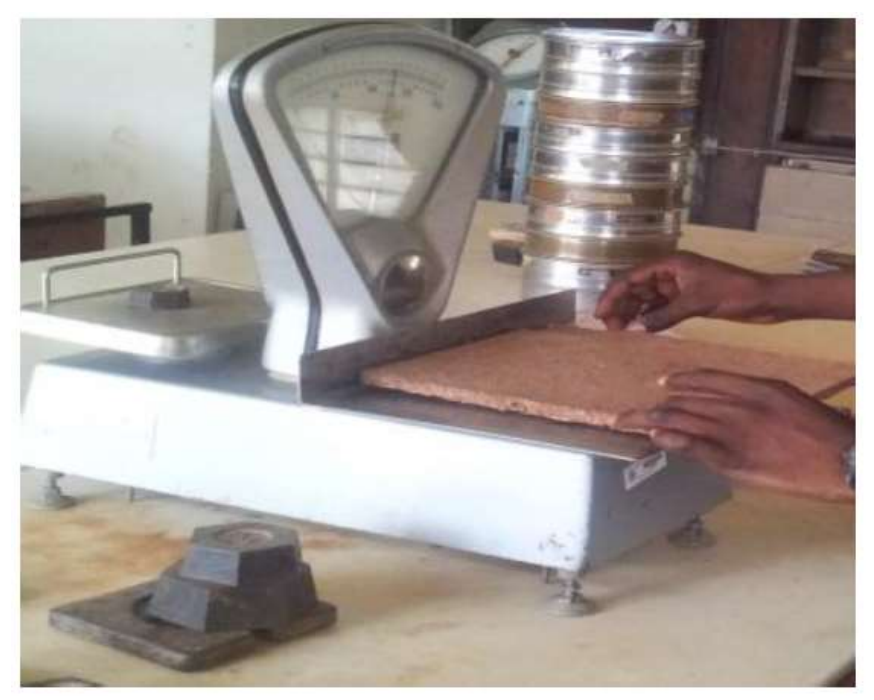

Figure 4. Measurement of the briquette mass on a weighing balance.

Table 2. The mass of wet briquette samples were obtained from the difference between the mass of mould + wet briquette and the mass of empty mould. From the Table, it was observed that wet sample C ( $50 \%$ pulp, $50 \%$ sawdust) has the highest mass followed by the wet sample B (70\% pulp, 30\% sawdust) and sample D (30\% pulp, 70\% sawdust). Wet sample A $(100 \%$ pulp) has the least mass slightly below the values of sample E $(100 \%$ sawdust). The results indicated that the water absorption tendency of both pulp (soaked waste paper) and sawdust are very similar with the sawdust having relatively higher absorption property than the wet waste paper.

\subsection{Moisture Loss}

After sun drying, the masses of the briquette samples were determined by direct weighing and the results were compared to the mass of the samples before sun drying to determine the moisture loss using Eqn. 1. The results are presented in Table 2, with the deviation from the mean values.

From the Table, it is observed that there was reduction in the masses of the samples after sun drying. This is due to the loss in the moisture content after the samples were dried. Sample A ( $100 \%$ pulp) has the highest percentage of moisture loss which is $80.77 \%$ (Fig. 5), indicating poor retention of water as a result of faster rate of drying. This observation may also be due to the low density of the sample A ( $100 \%$ pulp) compared to other briquette samples as revealed in Fig. 6. The lower the density of any material, the higher the presence of pores and the more the ability to loss moisture, that is, the less the water retention ability since there will be more spaces for the water/moisture to escape. Generally, as the 


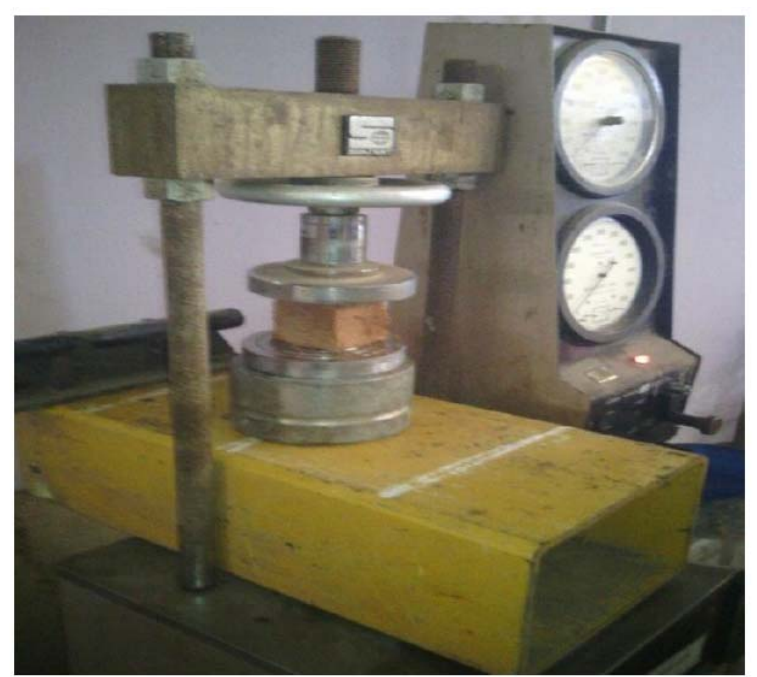

Figure 5. Compression test set up.
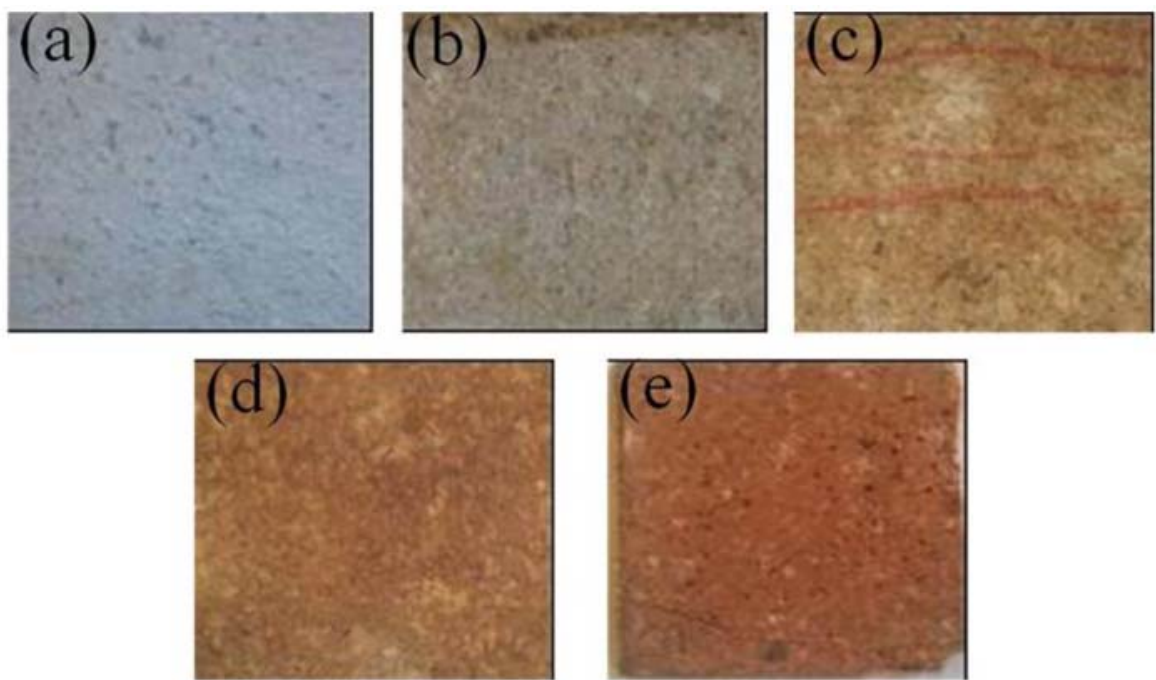

Figure 6. Pulp and sawdust briquette samples: (a) $100 \%$ pulp, (b) $70 \%$ pulp and $30 \%$ sawdust, (c) $50 \%$ pulp and $50 \%$ sawdust, (d) $30 \%$ pulp and $70 \%$ sawdust, and (e) $100 \%$ sawdust.

composition of pulp in the briquette samples increases, the percentage of moisture loss also increases as shown in Table 2. However, sample with equal amount of pulp and sawdust showed slightly higher moisture loss compared with sample with $70 \%$ pulp possibly due to homogeneity and better compaction. Sample E (100\% sawdust) retained more water and thus have lower percentage of moisture loss possibly due to slow rate of drying as shown in Fig. 7. This observation agrees with Fig. 8, which shows that sample $\mathrm{E}$ has the highest density among all the briquette samples. It is evident from the figure that sawdust retains more water than pulp due to better compaction resulting in improved density and lesser pores as compared to pulp.

\subsection{Density}

The density of each of the product was determined by dividing the mass of the dry briquette by its volume, which was obtained from the volume of the mould. The densities of each of the samples are presented in Fig. 8. It is observed that the density of the briquette samples increases as the composition of sawdust increases. The density of sample $\mathrm{A}$, which is purely made of waste paper $\left(100 \%\right.$ pulp), is $238.0 \mathrm{~kg} / \mathrm{m}^{3}$, while that of sample $\mathrm{E}$, which is $100 \%$ sawdust, is $497.6 \mathrm{~kg} / \mathrm{m}^{-3}$. 


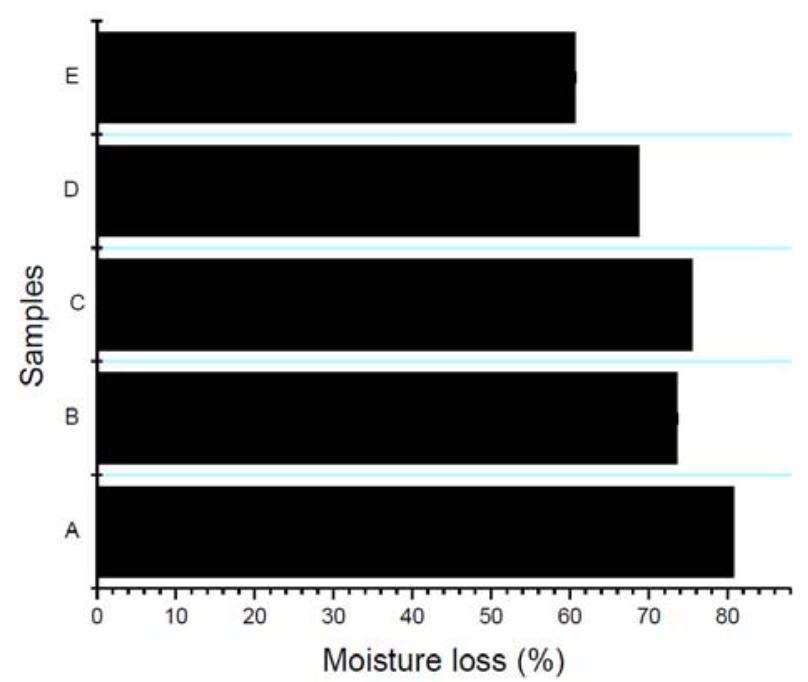

Figure 7. Percentage moisture of loss of paperboard samples.

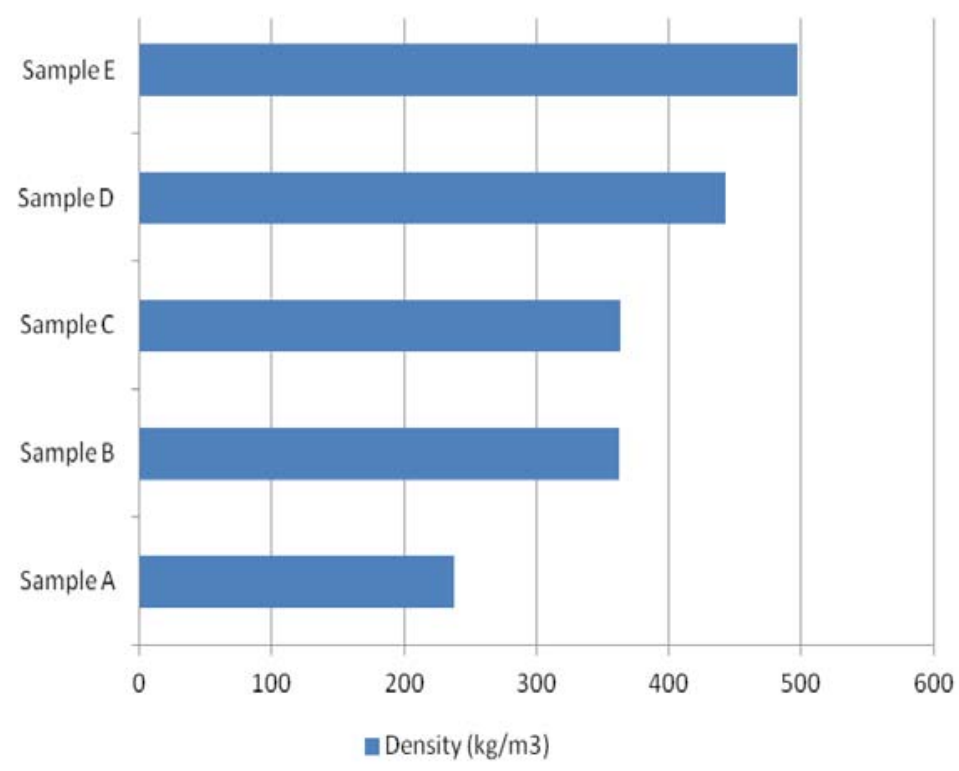

Figure 8. Density of various samples of paperboard.

This indicates that wood waste, that is, sawdust is denser than paper. Mahogany wood has been reported to have a density of between 495 and 850 $\mathrm{kg} / \mathrm{m}^{3}$, agreeing with the result of the present study. From the results, it can be concluded that sawdust imparts higher density to the paperboard compared to waste paper (pulp) due to better resulting from their relatively uniform grain sizes.

\subsection{Compressive Strength}

The compressive load of each of the samples was determined. Samples were made in cube with all the sides being $8 \mathrm{~cm}$ as shown in Fig. 3 prior to testing. The ratio of the load to the surface area of each cube was obtained to determine the compressive strength. The results are given in Table 3. It is clear from the table that sample A has the highest compressive strength. The compressive strength of the samples decreases as the composition of sawdust increases, indicating poor compressive strength of sawdust. Sample E, which is $100 \%$ sawdust, has the least compressive strength of $22.0 \pm 2.0 \mathrm{kPa}$. This may be due to its higher water retention capability resulting from poor compaction and presence of pores, and thus making the sample more brittle and easily shattered. Compressive strength has not been 
reported in most of the previous work found in the literature and thus making the comparison of the result in the current study to those in literature not feasible.

\subsection{Tensile Strength}

The tensile strength of each of the samples was determined using the centre loading system, where the load is uniformly distributed across the entire sample. The load at the point of failure is recorded. The mean tensile stress is then calculated and presented in Table 4 . The Table revealed that sample $\mathrm{B}$, which is $70 \%$ pulp and $30 \%$ sawdust, has the highest tensile strength of $628.9 \pm 0.8 \mathrm{~Pa}$. However, the tensile stress reduces as sawdust content in the paper board increases probably due to the poor tensile strength of sawdust resulting from its brittleness. Similar observation has not been reported in the literature on waste paper and sawdust briquettes. The tensile stress of sample E (100\% sawdust) could not be determined because the board did not bind properly. This shows that the sample is very brittle hence, it could not be loaded.

Table 3. Mean compressive strength of the paperboard briquette samples.

\begin{tabular}{lcc}
\hline \multicolumn{1}{c}{ Sample label } & $\begin{array}{c}\text { Mean Compressive } \\
\text { Force (N) }\end{array}$ & $\begin{array}{c}\text { Mean Compressive } \\
\text { Strength (kPa) }\end{array}$ \\
\hline A (100\% pulp) & $33375.0 \pm 0$ & $5215.0 \pm 0$ \\
B (70\% pulp, 30\% sawdust) & $14462.7 \pm 222.5$ & $2260.0 \pm 35.0$ \\
C (50\% pulp, 50\% sawdust) & $11347.7 \pm 222.5$ & $1773.0 \pm 35.0$ \\
D (30\% pulp, 70\% sawdust) & $3782.7 \pm 222.5$ & $591.0 \pm 35.0$ \\
E (100\% sawdust) & $141.3 \pm 12.7$ & $22.0 \pm 2.0$ \\
\hline
\end{tabular}

Table 4. Mean tensile strength of the paperboard briquette samples.

\begin{tabular}{lcc}
\hline \multicolumn{1}{c}{ Sample label } & $\begin{array}{c}\text { Mean Tensile } \\
\text { Force (N) }\end{array}$ & $\begin{array}{c}\text { Mean Tensile } \\
\text { Strength (Pa) }\end{array}$ \\
\hline A (100\% pulp) & $15.3 \pm 0.04$ & $426.7 \pm 1.4$ \\
B (70\% pulp, 30\% sawdust) & $22.5 \pm 0.03$ & $628.9 \pm 0.8$ \\
C (50\% pulp, 50\% sawdust) & $9.2 \pm 0.03$ & $257.0 \pm 0.8$ \\
D (30\% pulp, 70\% sawdust) & $5.2 \pm 0.03$ & $146.3 \pm 0.8$ \\
E (100\% sawdust) & - & - \\
\hline
\end{tabular}

\section{Conclusion}

Boards were produced from waste paper and sawdust using different mixing ratios and starch as binder. After production, tests were carried out on the boards to determine their properties. From the tests carried out and analyses done, it was observed that sawdust did not retain water as much as paper did. This explains why boards with higher paper content lost more mass than those with higher sawdust content.

Also, it is observed that sample B which is made of $70 \%$ paper and $30 \%$ sawdust has the highest tensile strength. This means it will be able to withstand bending to a reasonable extent without failing. It also has a relatively low density which makes it light in weight compared to other samples. Thus, $70 \%$ paper and $30 \%$ sawdust is recommended as the best mix ratio for production of quality and durable paper board.

\section{References}

Aina OM, Adetogun AC, Iyiola KA (2009), Heat energy from value-added sawdust briquettes of albizia zygia. Ethiopian Journal of Environmental Studies and Management 2(1): 2009.

British Standard Institution (1992), Determination of the tensile properties of paper and board. Constant rate of loading method. BS 4415-1:1992, ISO 1924-1: 1992.

British Standard Institution (2002), Paper and board. Compressive strength. Ring crush method. BS 1SO 12192:2002.

Brozek M, Novakova A (2013), Briquettes from recovered paper and board. Jelgava 23-24.05.2013.

Cocca M, D'Arienzo L, D'Orazio L (2011), Effects of different artificial agings on structure and properties of what man paper samples. International Scholarly Research Network ISRN Materials Science 2011: ID 863083, 7 pages doi:10.5402/2011/863083. 
Emerhi EA (2011), Physical and combustion properties of briquettes produced from sawdust of three hardwood species and different organic binders. Advances in Applied Science Research 2(6): 236-246.

Kercher AA, Nagle DC (2003), Monolithic activated carbon sheets from carbonized medium-density fiberboard. Carbon 41: 3-13.

Khezami L, Ould-Dris A, Capart R (2007), Activated carbon from thermo-compressed wood and other lignocellosic precursors. Bioresources 2(2): 193-209.

Kuti OA (2009), Performance of composite sawdust briquette fuel in a biomass stove under simulated condition. A.U. J.T. 12(4): 284-288.

Littrell KC, Khalili NR, Campbell M, Sandi G, Thiyagarajan $P$ (2000), Structure characterization of activated carbon adsorbents prepared from paper mill sluge. Chemical Material 14(1): 327-333.

Malikov IN, Noskova YA, Karaseva MS, Perederii MA (2007), Granulated sorbents from wood waste. Chemical Solid Fuel 41(2): 100-106.

Masahiro S, Iada T, Kawarada K, Chiba Y, Mamoto T, Okayama T (2004), Pore structure and adsorption properties of activated carbon prepared from granular molded waste paper. Journal of Mater Cycles Waste 6: 111-118.

Nakagawa Y, Molina-Sabio M, Rodriguez Reinoso F (2007), Modification of the porous structure along the preparation of activated carbon monoliths with $\mathrm{H}_{3} \mathrm{PO}_{4}$ and $\mathrm{ZnCl}_{2}$. Microprocessor Mesopor. Material 103: 29-34.
Nováková A, Brožek M (2011), Briquettes from paper waste. In.: Ecology and farming technologies: Agro-engineering approaches. Saint-Petersburg-Pavlovsk: Russian academy of agricultural sciences et al. 219-225.

Plíštil D, Brožek M, Malaták J, Heneman P (2004), Heating briquettes from energy crops. Research in Agricultural Engineering 50: 136-139.

Rizki M, Tamai Y, Takashi Y, Terazawa M (2010), Scrutiny on physical properties of sawdust from tropical commercial wood species: Effects of Different Mills and Sawdust's Particle Size. Journal of Forestry Research 7(1): 20-23.

Tangsathit S, Sanongraj S (2012), Technique for production of paperboard briquette from wastepaper. Suranaree Journal of Science and Technology 19(2): 79-92.

Thaemngoen C, Sungwornpatansakul W, Asavapisit S (2003), The potential for utilization of bagasse and eucalyptus pulp slugs from wastewater treatment plants of the pulp industries to produce fiber-cement composites. Suranaree Journal of Science and Technology 11: 125-131.

Uradei Y, Technol, Taniwatashi R, Kubo S (2000), Activated carbon sheet prepared from softwood acetic acid lignin. Journal of Wood Science 46: 5258.

Yorgun S, Vural N, Demiral H (2009), Preparation of high-surface-area activated carbons from paulownia wood by $\mathrm{ZnCl}_{2}$ activation. Microporous and Mesoporous Materials 122: 189-194. 